\title{
Ghana Hotel Industry (Three-Five Star Rated) And Covid-19: Present Scenario And The Way Forward
}

\author{
Bertha Ada Danso ${ }^{1}$, Nana Akua Osei-Tutu ${ }^{2}$, Theodora Naa Maamle Whyte ${ }^{3}$, and Elias Nii Noi Ocquaye \\ 1 Hospitality Department, Takoradi Technical University, P.O. Box 256, Takoradi, Western Region, Ghana \\ 2 Vocational Technical Department, Wiawso College of Education, P.O.Box 97, Sefwi-Wiawso, Western North Region, Ghana \\ 3 TKM Hospitality services, P.O.Box Yk 1426, Greater-Accra Region Ghana \\ 4 Data Link Institute of Businesses and Technology P. O. Box CO 2481 Tema, Ghana
}

\author{
Article History \\ Received: 01.09.2020 \\ Accepted: 17.09 .2020 \\ Published: 30.09.2020 \\ Journal homepage: \\ http://www.easpublisher.com/easjals/
}

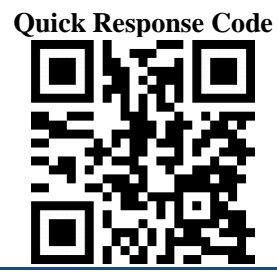

Abstract: Many studies on the impact of the COVID-19 pandemic are being conducted on various sectors such as health, finance and travel industry at large. This paper tries to assess the current and likely after effects of COVID-19 on hotel operations in Ghana, using the 3 to 5 star rated hotels as a case. The sample size was 50 out of the 55 hotels in this category in the country. The mixed approach was used to collect data by the use of questionnaire with both open and closed ended questions. Microsoft excel was used in the data analysis. The study found that the occupancy rate, operation capacity and employment were affected drastically by the pandemic therefore; it is recommended that hotels employ the use of discounts and promotions to attract guests. Industry players should sign up to insurance policies that can help cushion their businesses in times of crises.

Keywords: COVID-19, Pandemic, Star Rated Hotels, Hospitality Industry, Ghana, And Novel Corona Virus.

Copyright @ 2020: This is an open-access article distributed under the terms of the Creative Commons Attribution license which permits unrestricted use, distribution, and reproduction in any medium for non-commercial use (Non Commercial, or CC-BY-NC) provided the original author and source are credited.

\section{INTRODUCTION}

The study aims to measure the corona virus pandemic effect on the hotel industry in Ghana, the present scenario and the possible ways the industry can recover from the downturn.

Pneumonia of unknown cause spotted in Wuhan, China, was first reported to the country office of WHO in China on 31 December 2019. In early January 2020, 41 patients with confirmed infections by novel coronavirus (COVID-19) had been admitted to hospitals in China Huang et al., (2020). Even though the spread of the virus was fast in the country's Wuhan region, it was initially largely overlooked by political Leaders in other parts of the world (although intelligence services issues warnings of a probable cataclysmic event;(Thebault, Tran, \& Williams, 2020).

The growth of the hospitality industry has seen interruptions at various key points in history, this includes, World War I, the great Depression, and World War II (Lorde \& Joseph, 2019). This century began with global events that pushed international travel into decline such as the September 11, 2001, attack on the world trade center in New York City (9/11), the war in Iraq, seeming threat of future terrorist attacks, and scary health issues like SARS, BSE (bovine spongiform
encephalopathy),West Nile virus and Ebola virus. Barely a few years to end the first quarter of the century, another global health trepidation emanates Coronavirus disease 2019 (COVID-19) and according to Chakraborty and Maity (2020), it is considered as the most critical universal health catastrophe of the century and the utmost challenge that has faced humankind since World War II.

As per rekha Hanumanthu (2020), World Health Organization report (WHO as of May 26, 2020), COVID-19 outbreak has over 5406282 people infected in 216 countries all over the world. COVID-19 has become a challenge to the world leaving businesses around the world to count the cost of its spread. Jain (2020), reports of a pizza delivery boy in Delhi who tested positive and had 72 families and 15 staff isolated for further management.

The novel corona virus has taken its course in Ghana infesting people through community contacts with persons who have it. The pandemic was reported as starting its spread in Ghana through infested persons who arrived in Ghana from other countries, such as Turkey, Norway, Germany, Great Britain, USA and others. With an initial two (2) reported cases, the surge in numbers between March and May 2020 now stands at over 17,000 (Hoarau, 2020; Organization, 2020). 
The hotel industry faces one of its most severe operational, commercial and financial crises due to the wide-reaching spread of COVID-19. According to the 19th July Worldometer report, a total of 213 countries and territories around the globe have reported a total of $14,422,468$ confirmed cases of the virus as at mid-July 2020. The novel corona virus has had a toll on almost every industry and everyone across the globe (Nicola et $a l .,, 2020)$. It is very obvious the hospitality industry is among the hardest hit with real economic impact. The global pandemic has held airplanes, shutdown hotels, and affected the tourism industry in various ways. As a result; travel supply and demand has decreased. Strong and Welburn (2020), posits that the American Hotel and Lodging Association (AHLA), reports that Hotels employ approximately $4 \%$ of the total U.S. workforce, close to 8.3 million people. Many of these employees are out of work in present times or losing hours because of limited travel owing to COVID-19 (Dwyer, Forsyth, \& Dwyer, 2020; Edwards, 2020; Fairlie, 2020).

Ghana is a developing country and according to the Ghana Statistical Service (2016) it is an economy that grew at $4.5 \%$ in 2015 and similar projections are expected for 2016 and onwards. Meanwhile, the country recorded GHC 3.7M (USD 880 000) in visitor exports in 2015. In 2016, it was expected to attract 1,316000 international tourists arrivals, and 1,913,000, by 2026 thus generate outgoings of GHC 4.7M (USD $1.12 \mathrm{M})$ a rise of $2.5 \%$ pa. Current statistics show that, the express contribution of Hotel, Travel\& Tourism to GDP in 2016 was GHC 4.9M (USD 1.2M) (3\% of GDP). This forecast is to rise by $5.6 \%$ to GHC $5.2 \mathrm{M}$ (USD $1.2 \mathrm{M}$ ) in 2017 and by $5.1 \%$ pa to GHC $8.6 \mathrm{M}$ (USD 2M) (2.9 of GDP) by 2027(Ansah, 2019; BOASIAKO).

There are already over 1,595 established hotels of various star ratings in Ghana. Statistics from the Ghana Statistical Service 2016 has it that the sector was the fourth highest foreign exchange earner for Ghana, and the country earned a total of US $\$ 1.3$ billion in 2014 from the sector. Being one of the fastest-growing sectors of the economy it is likely to grow at an average rate of 4.1 Percent per annum over the next two decades (Service, 2016).

With the worldwide travel, bans touching more than $90 \%$ of the global population as well as the prevailing restriction on public gatherings and community mobility, tourism generally ceased in March 2020. Initial indications of effects on air travel, cruises and accommodations have been disturbing (Gössling, Scott, \& Hall, 2020; Idris \& Oruonye, 2020). UNWTO initial projections for 2020 propose that international travels could decline by $20-30 \%$ compared to 2019 (Becken \& Carmignani, 2020).
Ghana joined the ranks of countries that are enforcing some form of constraint on movement with the hope of slowing down the increase of the disease as it recorded its first cases in March 2020. Presently, the number of infected people is on the rise yet steadily. The outbreak of the disease has slowed down business activities, which will eventually affect revenue. OwusuFordjour, Koomson, and Hanson (2020), as well as Dr. Raymond Dziwornu, Dean, Faculty of Accounting and Finance, University of Professional Studies, Accra, opine that, the administration is expected to overlook its first quarter revenue goal for the year due to the bang of COVID-19 global pandemic.

Hotels, restaurants and other destinations and source markets have been badly affected and have suspended operations and commercial activities due to the partial to permanent closure of international borders.(Hartman \& Nickerson, 2020; Kim, Kim, \& Park, 2020; Nastopoulos, 2020).

Against this background of an evolving global pandemic, this paper has two objectives. First, to identify the effects of the coronavirus pandemic on the hotels (3-5 Star rated) in Ghana. Second, ascertain possible post COVID-19 pandemic effects on the hotel business in Ghana (3-5 Star rated). Owing that, the further spread of COVID-19 pandemic in Ghana might create devastating long-term effect on the hotel trade locally and internationally.

\section{REVIEW OF LITERATURE AND THEORIES \\ Theoretical background}

This study thrives on the theory of crisis management. Crises management is very essential in the sustenance of businesses. Ineffective crisis management can result in the collapse of a business if the unfortunate (crises) hits it. A crisis is defined as a situation that can threaten activities with negative consequences if not handled effectively. The COVID19 pandemic can therefore be described as a crisis to the Ghanaian hotel industry and the hotel business internationally. Management of crisis can be divided into three phases: pre-crisis, crisis response and postcrisis (Bundy, Pfarrer, Short, \& Coombs, 2017; Milojevic \& Katsadze, 2020; Wang \& Wanjek, 2018).

Significant policy attention has focused on the need to identify and limit emerging outbreaks that might lead to pandemics and to expand and sustain investment to build preparedness and health capacity (Lederberg, Hamburg, \& Smolinski, 2003; Smolinski \& Hamburg). The framework put into place by the updated international Health Regulations (IHR) which compels all World Health organization member state to meet specific standards for detecting, reporting on and responding to outbreaks (Smith, Tang, \& Nutbeam, 2006). Despite these improvements, significant gaps 
and challenges exist in global pandemic preparedness. Progress toward meeting the IHR has been uneven, and many countries have been unable to meet specific requirements for compliance (Brady et al.,, 2012; Fischer \& Katz, 2013).

These gaps are especially evident in resourcelimited settings and have posed challenges during relatively localized epidemics with severe consequence for full-fledged global pandemic.

The most cost effective strategies for increasing pandemics preparedness, especially in resource -constraint settings requires investment to strengthen core public health infrastructure, including water and sanitation systems; increasing situational awareness and rapidly extinguishing sparks that could lead to pandemics. Successful contingency planning and response require surge capacity - the ability to scale up the delivery of health interventions proportionately for the severity of the event, the pathogen and the population at risk(Organization, 2018).

\section{Effects of COVID-19 pandemic on the world at large}

The COVID-19 pandemic has inevitably eroded national economies across the globe and the continuous surge in numbers would eventually affect almost all sectors of economies if the spread continues. According to Lee and Warner (2006), the impacts of this virus has not only disrupted human lives which is a major resource for production and various service delivery sectors but have crippled fast growing economies. Kickbusch et al., (2020), cites how Bloomberg, 2020 estimates that in an endemic situation, COVID-19 may possibly cost the world economy $\$ 2.7$ trillion equivalent to UK's economy. This could lead to developing countries and budding economies being drastically impacted without support in the form of development aid, debt relieve and debt restructuring. There has been multifaceted response from multilateral institutions towards mitigating the economic impact(Chattu, Adisesh, \& Yaya, 2020; Kickbusch et al.,, 2020).

According to Baker et al., (2020), no earlier infectious disease outburst including the Spanish flu has impacted the stock market as forcefully as the COVID19 pandemic. They also argued that policy responses to the COVID-19 pandemic offer the most gripping explanation for the extraordinary stock market impact. Ramelli and Wagner (2020), indicates that economic turmoil associated with COVID-19 pandemic has had wide-ranging and severe impact upon financial markets, including stock, bond and commodity markets (including crude oil and gold).

By the Organization for Economic Cooperation and Development (OECD) standards, Spain, Italy and France have very weak pension asset bases (Boersch-Supan \& Winter, 2001). Their combined pension wealth is more than 15 times smaller than that of jurisdiction such as the UK or Australia(Boersch-Supan \& Winter, 2001; Jedynak, 2020). In times of acute crises like the one presently being witnessed, they lack cash-rich domestic buyers of last resort for the bonds and equalities traded on their financial markets (Franco \& Tommasino, 2020). The OECD stated that businesses in numerous countries have become extremely indebted while the very low cost of borrowing and accommodative monetary policy have contributed to unprecedented corporate debt issuance. Thus, with corporate debt standing at very elevated levels in many G20 countries businesses will have little choice than to reduce costs and employment to withstand insolvency pressures. Governments across the globe: France, Switzerland, Spain, Ghana and many more have promised aid to support all types of local businesses impacted by COVID-19.

Ataguba (2020), asserted that early estimates predicted that, should the virus become a global pandemic, most economies will lose 2-4 percent of the value their gross domestic product (GDP) over 22020 leading economists to already reduce their 2020 forecasts of global economic growth down from around 3.0 percent to 2.4 percent. This forecast consequently estimated global GDP around 86.6 trillion US dollars in 2019 - meaning that a 0.4 percent drop in economic growth amounts to almost 3.5 trillion U.S dollars in lost economic output(Zhang, Hu, \& Ji, 2020). However, the predictions were made prior to COVID-19 becoming a global pandemic and before the implementation of widespread restrictions and social distancing to curb the spread of virus. With the virus at a pandemic stage, international stock markets have suffered vivid falls due to the eruption (Sansa, 2020). Nicola et al., (2020), touches on Dow Jones report on 15th June,2020 that fear is once again gaining the upper hand on Wall Street with signs of an emerging second wave of COVID-19 infections surfacing. The Dow Jones industrial fell more than 600 points or 2.3 percent minutes into re-opening of trading in New York (Cherkaoui, 2020; Kantamneni, 2020).

Education has also been affected by the pandemic and students from the basic level of education up to tertiary level have to learn from home through online learning and blended learning sessions (Ehrlich, McKenney, \& Elkbuli, 2020).

\section{Effects of COVID-19 on the hospitality industry in Ghana}

The hospitality industry in Ghana has noteworthy potential to drive economic growth and job creation increasingly an area of focus for venture in Ghana.(Zhe \& Bawuah, 2019) In 2017, the sector contributed GHS12.58bn ( $\$ 2.7$ bn) or 6.2 percent to national GDP. A total of $1.3 \mathrm{~m}$ international tourists visited the country that same year, representing 6 
percent increase compared to 2016. In terms of employment the World Travel and Tourism Council reported that the sector supported 682,000 jobs, or 5.3 percent of national employment in 2017 (Adu-Ampong, 2017). The outbreak of the novel corona virus disease (COVID-19) has disrupted every aspect of the Ghanaian economy especially the hospitality industry (Amewu, Asante, Pauw, \& Thurlow, 2020).

The present COVID-19 pandemic in Kabadayi, O'Connor, and Tuzovic (2020) view, will undeniably hamper the country's hospitality industry performance and expected revenue for economic impacts. Job losses, low profit margins and further disruptions of supply chains are some of the negative shock of COVID-19 on the hospitality industry.

\section{The hospitality industry encompasses three different categories namely:}

Food \& Beverage- restaurants, stores and bars

Tourism- Parks, flights, trains, buses, heritage sites, natural sites, cultural museums, theatre and other unique sites to the area and country

Hotels - Hotels, guesthouses, lodges, hostels and rental condominiums

According to the World Travel and Tourism Council (WTTC), the COVID-19 pandemic could cut 50 million jobs globally in the travel and tourism industry. WTTC predicted that it would take up to 10 months for the sector to return to its normal level (Gössling et al.,, 2020; Haryanto, 2020; Polyzos, Samitas, \& Spyridou, 2020).

\section{COVID-19 and the Ghanaian hotel industry explicitly}

The hotel industry in Ghana like other industries in global economies has experienced a down turn due to the COVID-19 pandemic. The bank of Ghana describes the industry as the fourth uppermost foreign currency earner for the country but will sadly not be able to generate the needed revenue in 2020 for the economy due to the spread of the pandemic (Badu, Thorn, Goonoo, Dukhi, \& Sylverken, 2020; Ozili \& Arun, 2020).

The introduction of Partial lockdowns, closure of boarders, stay-at-home policy and social distancing announced by the government in March 2020 as part of measures to curb the spread unfortunately resulted in rapid shutdowns by most cities and metropolis. The resulting effects from these measures threw several restaurants and hotels across the country into abrupt shock. Hotel bookings worth millions of dollars were cancelled; hotel owners laid-off staff while others were asked to proceed on leave without salary,(Abay, Tafere, \& Woldemichael, 2020; Milojevic \& Katsadze, 2020).

Major services provided by hotels such as restaurant, swimming pool, conferences and events were all badly affected due to non-availability of customers to consume the services provided. Profits margins have been eroded and the bottom line badly affected. According to the data published by STR a global data firm in March 2020, a spiky drop of occupancy rates from $96 \%$ in the global hospitality is expected because of the pandemic(Ivanov, Webster, Stoilova, \& Slobodskoy, 2020; Ranasinghe et al.,, 2020).

Due to the decline in hotel occupancy during the pandemic period, the economic impact of COVID19 pandemic on the hotel industry is more than the 9/11 and 2008 downturn combined asserted by (Ozili \& Arun, 2020). The major source of revenue for the hotel industry in Ghana is room occupancy mainly contributed by foreign influx of travelers from across the globe (Lestari \& Saputra, 2018). Should the COVID-19 pandemic persist, should boarder closures and temporary bans on movement be extended or reintroduced, the impact and further disruption to hotel business could be deeper and damaging.

In Ghana, hotel occupancy rate are down from 70 percent to 30 percent with some hotels recording as low as 5 percent. According to him though the hotels are experiencing considerable revenue losses, utilities, wages and salaries as well as other recurring expenditure and payments that are statutory will have to be made. (Adom, Adu-Mensah, \& Sekyere, 2020)

There is a general agreement that the industry will not be the same long after the lockdowns and travel limitations have been lifted. Hoteliers cannot afford to follow the existing model of business operation but must adopt survival strategies against COVID-19 (Adom et al.,, 2020; Ozili \& Arun, 2020).

\section{Post COVID-19 pandemic effects on the hotel industry}

From a study by Niewiadomski (2020), it was established that for many years, the hospitality, travel, tourism and events industry (HITTTE) dominated the world until COVID-19 brought the ever buoyant industry to ground zero. Global and local markets have all but collapsed and governments around the globe are working tirelessly to strike a balance between keeping their market economies going, averting unemployment and deprivation of the poor while trying to respond to public health essentials (Bakar \& Rosbi, 2020).

They further asserted that before COVID-19, there were concerns about over-tourism (overcrowding from the excess influx of tourist, which often resulted in conflicts with locals) as well as exceeding of ecological thresholds and climate change due to tourism. Now it seems the pendulum has swung to the other end and under-tourism is what industry players may have to be troubled about. In the current situation industry players will have to draw lessons from the situation and use the 
lessons to reposition their facilities (Bakar \& Rosbi, 2020).

The COVID-19 pandemic is surely going to bring change globally as many industry organizations have published estimates of the consequences. Businesses can use these estimates to effect change in the business to ensure survival. Video conferencing is an under-utilized opportunity to reduce transport demand (Gemar, Soler, \& Guzman-Parra, 2019).

The hospitality industry is headed for an unprecedented slump from COVID-19. According to experts the pandemic will remain for about 2 years, because the fear of travelling and enforcement of social distance protocols will not go away soon after the pandemic subsides (Sarkodie \& Owusu, 2020).

A scheduled international conference- 4th African Union in Ghana had to be cancelled because of the COVID-19 pandemic. Hospitality businesses like hotels, airline and tourism have been greatly affected.

A Specialized Technical committee on Finance, Monetary affairs, Economic Planning and Integration meeting and the G24 meetings which was to take place in Accra- Ghana on March 2020 had to be cancelled resulting in the loss of 1000 hotel beds reserved as reported in Ghana Ministry of Finance report, April 2020 and cited in (Amewu et al.,, 2020).

In the post- COVID-19 world, Jain (2020), states that Island sitting which reinforces the social distancing protocol, live cooking contests to inspire confidence in diners, preference of bottled drinks over dispensers, proper and regular sanitation protocols and low staff to customer ratio are expected.

Gössling et al., (2020), maintain that, in the restaurant sector, the easing of restriction especially social distancing will favor fast food and home deliveries over fine dining restaurants. The recovery of cruise ships as suggested by many authors is only possible with the introduction of a vaccine. The HTTTE and post COVID-19 scenario requires both private and public stakeholder engagements to rethink operational practices within the sector (Di Vaio, Boccia, Landriani, \& Palladino, 2020).

Digitalization is expected to be the norm for conferencing and the likes. According to (Gössling et al., (2020); Hussain (2020)), the European council, the G20 leader's meeting on the 26th March 2020 had for the first time been organized through video conferencing.

Green tourism will be a major approach industry players will have to embark upon to revamp the tourism industry since businesses do not exit to only make profit but rather to care for the environment they operate in (Dube, 2020).

Post COVID-19 according to Mensah (2020), requires hotel owners and managers to take major steps to institute crisis management plans, which must embody survival strategies namely cost-cutting, orderliness, Integration and domestication. Repackaging of the hospitality services to make it more attractive in this situation could help drive traffic to various hospitality service providers. The driving force behind the industry recovery is the SMEs hotels however; they need to be supported by government to remain relevant in this area.

A clear understanding of the measures to be undertaken by hotel owners, flexibility and the right policy guideline will make the hotel industry robust again in a post COVID-19 era.

\section{Methodology \\ Research Design}

The descriptive research design was used in this study. This encompasses surveys, interviews, observation, and data reviews. Descriptive research design has to do with conditions, practices, structures, opinions, differences, current trends among others. This research design was used as information was gathered basically from hotel managers and supervisors then presented in a descriptive manner. (Rhou \& Singal, 2020). A measurement scale was developed to measure; first the bang of COVID-19 on the hotel industry (3-5 Star) and second the post COVID-19 pandemic changes likely to affect the hotel industry in Ghana.

\section{Research approach}

The mixed approach was used whereby quantitative and qualitative data was collected by the use of questionnaire with both open and closed ended questions to identify, select, process and analyze data regarding the research. Interview was also conducted online to clarify responses to the questionnaire. An online-based questionnaire was shared through WhatsApp and email to hotels within the 3 to 5 star category. This approach was used due to the COVID-19 pandemic forcing most employees to stay at home hence the need to engage the respondent on the most convenient media platforms accessible to them. Fifty five (55) questionnaire were administered and 25 respondents were interviewed as well. The respondents had a typical organizational tenure of 10-5 years and were working in different departments such as the Front Office, Food \& Beverage, Security, Housekeeping and Pool. The questionnaire was pilot texted on 30 respondents after which it was finalized to include the following categories as displayed in appendix 1 Demographics, COVID-19 effects on the hotel's operation (occupancy before and during COVID-19), Hotels' operational capacities (before and during COVID-19), the effects of COVID-19 on staff 
employment and post COVID-19 changes likely to occur in the hotel industry.

\section{Population and sample size}

Population of a study is primarily the respondents, which consist of people who meet the specific benchmark of a research. Supervisors and heads of departments in the 3-5 star rated hotels in Ghana were the population of this study. The study employed the use of three to five (3-5) star rated hotels due to time factor and also because prior enquiry revealed that most hotels that are not three, four, or five star rated were not in operation at the time of the survey and that some opted to be used as isolation centers. There are over seven hundred (700) star rated hotels in Ghana yet those that fall within the scope of this research are only 55 as indicated in Table 1. Fifty (50) out of fifty five (55) responses from three to five (3-5) star hotels in Ghana that are affiliated with the hospitality and tourism regulatory institution -Ghana Tourism Authority (GTA) were used. This is because five (5) of the responses were incomplete.

Table 1: Summary of 3-5 Star Rated hotels in Ghana (2018)

\begin{tabular}{llll}
\hline REGIONS & 5 Star & 4 Star & 3 Star \\
\hline Greater Accra & 3 & 7 & 7 \\
Tema & & 1 & 1 \\
Ashanti & & 2 & 8 \\
Eastern & 2 & 7 \\
Western & & 8 \\
Central & & 5 \\
Brong Ahafo & & 1 \\
Volta & & 3 \\
Northern & & \\
Upper East & & \\
Upper West & 3 & 12 & 40 \\
TOTAL & & \\
\hline
\end{tabular}

Summary of 3-5 Star Rated hotels in Ghana (2018) from G.T.A. and compiled by authors

\section{Data collection instrument and procedure}

The survey consisted of three sections. The first section is made up of seven questions aimed at collecting the demographic data of respondents. The other two sections consisting of eight and eleven questions respectively were developed in relation to the variables of interest based on the objectives of the study. The answers received from the respondents for these sections helped the researcher to achieve the objectives of the study.

Upon approval from the respective management of the hotels, the questionnaire were distributed with their help through a single faced survey questionnaire accompanied by a cover letter introducing the rationale of the study, assuring voluntary participation, anonymity and confidentiality. This approach was adopted by Yang (2020), and was conducted over a period of two weeks (16th to 28th June 2020), during which the respondent were asked to measure the impact of the COVID-19 pandemic on their operations and to identify the likely changes a post COVID-19 effect will have on the hospitality industry. The questionnaire was sent to 55 departmental heads and supervisors. The questionnaire received viewing while only 50 were completed and returned. For the purpose of good analysis, only fully completed responses was selected and used for the results and discussion. An online survey was appropriate because of the social distancing protocol during the COVID-19 period. Additional data were also collected through observation and a few interviews the researcher had with significant industry players.

\section{Data Analysis}

The purpose of data examination is to reduce and transform the data collected to comprehensible and interpretable form so that the relations of the research problems can be tested and conclusions drawn from it. Data was analyzed and presented in figures by the survey tool (surveyhero) and Microsoft excel which were used in analyzing the present effects and possible changes that COVID-19 would impact on the hotels in Ghana.

\section{Ethical Consideration}

The researchers sought the consent of all participants who were willing to take part in answering the questionnaire and granting the ensuring confidentiality of information obtained and anonymity of the respondents (Ary, Jacobs, Irvine, \& Walker, 2018).

\section{RESULTS AND DiSCUSSION Demographic Information}

From the survey, it was identified that 81 percent of most 3-5 star rated hotels in Ghana are privately owned. Whiles 11 percent and 8 percent of the hotels are owned through partnership and franchise, respectively. In addition, most of these hotels fall within the 6 to 10 years of existence category. It can also be said that most of the 3-5 star rated hotels in Ghana are more than 6 years old. 
The survey indicated that there are 403 -star rated hotels in Ghana and out of that, 37 of them participated. Most of the 3 star rated hotels are privately owned and they can be found in the major cities namely Accra being the capital, Kumasi being the business city and Takoradi being the oil hub of Ghana. Majority of the hotels from the survey have more than 50 rooms.
What it also means is that Ghana has quite a lot of large hotels.

Also from the survey, we identified that hotels with 15 to 30 employees are more next were the hotels with 31-60 and over 90 employees meaning hotels in Ghana employ more personnel. Through the interview session, we also identified that not all the employees are permanent staff; some are casual and contract staff.

Table 2. Demographic Information of Respondents $\mathrm{N}=50$

\begin{tabular}{lcc}
\hline Demographics & Frequency & Percentage (\%) \\
\hline Ownership & 40 & 81 \\
Private & 8 & 11 \\
Partnership & 4 & 8 \\
Franchise & & \\
Yearsof Existence & 10 & 20 \\
$1-5$ & 17 & 34 \\
$6-10$ & 7 & 14 \\
$11-15$ & 16 & 32 \\
$16 \&$ above & & 79 \\
Star Rating & 37 & 20 \\
$3 *$ & 10 & 1 \\
$4 *$ & 3 & 25 \\
$5 *$ & & 9 \\
Numberof Rooms & 12 & 9 \\
$20-30$ & 5 & 57 \\
$31-40$ & 5 & 30 \\
$41-50$ & 28 & 26 \\
$51 \&$ above & & 18 \\
Numberof Employees & 15 & 26 \\
$15-30$ & 13 & \\
$31-60$ & 9 & \\
$61-90$ & 13 & \\
$90 \&$ above & & \\
\hline
\end{tabular}

Source: Fieldwork June 2020

\section{Current Effects of COVID-19 on Ghanaian Hotels}

In this segment, we analyzed the effects considering the patronages of the hotel services and the employees' wellbeing as well as the actions taken on them. We visualized the effects of COVID-19 on the hotels using different graphs.

\section{Hotel Service Patronage}

Figure 1 gives a pictorial representation on the effects of COVID-19 on the patronage of the hotel services.

In Figure 1(a) Majority of the hotels had more than 50 percent occupancy before the emergence of the COVID19. This means that business was good for majority of the hotels surveyed prior to the pandemic. It also means that more economic activities were created for the self-employed businesses within the value chain and it supports the point that the hospitality industry contribute immensely to the GDP of the nation (Service, 2016).

In Figure 1(b) majority of the hotels had occupancy within the series of $01 \%-25 \%$ this implies that before the COVID-19, business was booming for the hotels compared to the current situation where business is completely down. The hotel industry is badly affected resulting in low revenue and less of profit margin. From the data collected in this research, a vast majority of hotels, compared to business before the COVID-19 pandemic were dissatisfied with their operating capacity now. Now with COVID-19 pandemic still around describe the period before COVID-19 can be described as pre-crisis and the period as the crisis response (Coombs, 2007). Before the COVID-19 pandemic hotel, managers may have put in standard measures and policies that were intended to keep them afloat. This is a unique feature of the post-crisis stage where management is always looking for ways to maximize productivity and prevent loses. 
Halfway through 2020, it is so evident that the COVID-19 pandemic has really shaken the global economy and businesses: hotels, retail shops, food and beverage outlets, event organizers and the like have temporarily closed their doors. Tourism is down due to social distancing and restriction on international borders(Gössling et al.,, 2020).

From Figure 1(c), the survey indicated that over 22 percent of the 3-5 star rated hotels were dissatisfied with the current state they had to operate in. This shows the true reflection of how COVID-19 has negatively affected the operations of the top rated hotels in Ghana. The unset of COVID-19 though its impact far reaching can also create opportunities for businesses to incorporate the habit of setting aside a fund investment to better manage future pandemics instead of fully utilizing all cash flows on business operations during peak business cycles.

A close look at Figure 1(d) and 1(e) show the operating capacity before and during COVID-19, respectively. Before the COVID-19, the operating capacity was above 70 percent meaning the hotels who participated fully utilized their capacities, which generated more revenue for them.

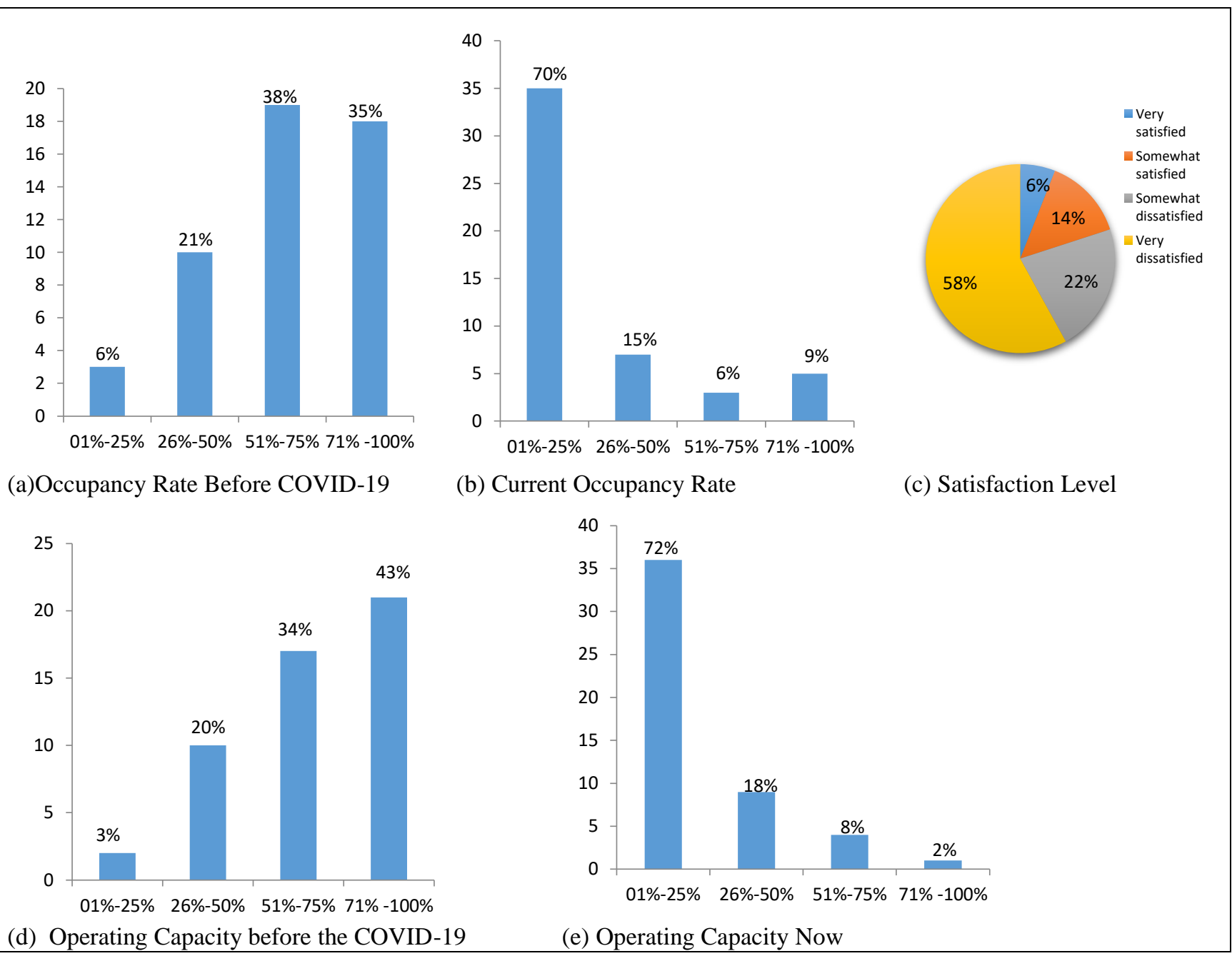

Source: Fieldwork June 2020

Figure 1: Graphs of COVID-19 Effects on Hotel Services Patronage

During the COVID-19, the operating capacity of most hotels fell within the range of $01 \%-25 \%$. On further probing, it was revealed that, the following revenue generating centers were under-utilized causing a sharp drop in revenue:

Rooms were empty due to the lock down, restrictions on movement and temporary closure of boarders.
Restaurant had low utilization because of social distancing and the fact that most people did not feel safe eating in a sit-in dining experience but rather opted for take-away service joint.

Conference and event halls were equally empty due to cancellation of conferences and public gathering. Most customers utilized on-line based meeting apps as substitute for traditional meetings. 
Laundry services were also under-utilized due to lock down measures.

Swimming pool usage was down as there were no in-house guests to patronize.

The casual guests who use membership cards also abandoned the usage.

The COVID-19 pandemic has therefore posed an important risk for hotels revenue streams and it is imperative for hotel owners and managers to have a capacity plan for contingencies, which will allow proper management of capacity even in a pandemic situation.

\section{Employee Wellbeing}

Figure 2 gives a pictorial representation on the effects of COVID-19 on the employees' wellbeing and maintenance of the hotel brand before and during the spread of the virus.

In Figure 2 (a), amidst the COVID-19 pandemic the hotels who participated are able to carry out periodic maintenance to maintain the facility for their cherished guests. It is also to keep their brand and make it a preferred option for business. Crisis response is what is done after a crisis occur. Health experts have recommended a number of protocols to help manage the pandemic such as regular hand washing and the use of nose masks. Installation of automated sanitizer dispenser at the public areas and guest rooms will also be part of the maintenance. One may think that amidst the severity of the pandemic bang on the hotel business they are still able to maintain their brand.

From Figure 2(b), despite the COVID-19 hotels still trained their staff in COVID-19 protocols to ensure staff are protected and learn how to take care of themselves. The hotels also saw it as an opportunity to train their staff since there was little or no work available.

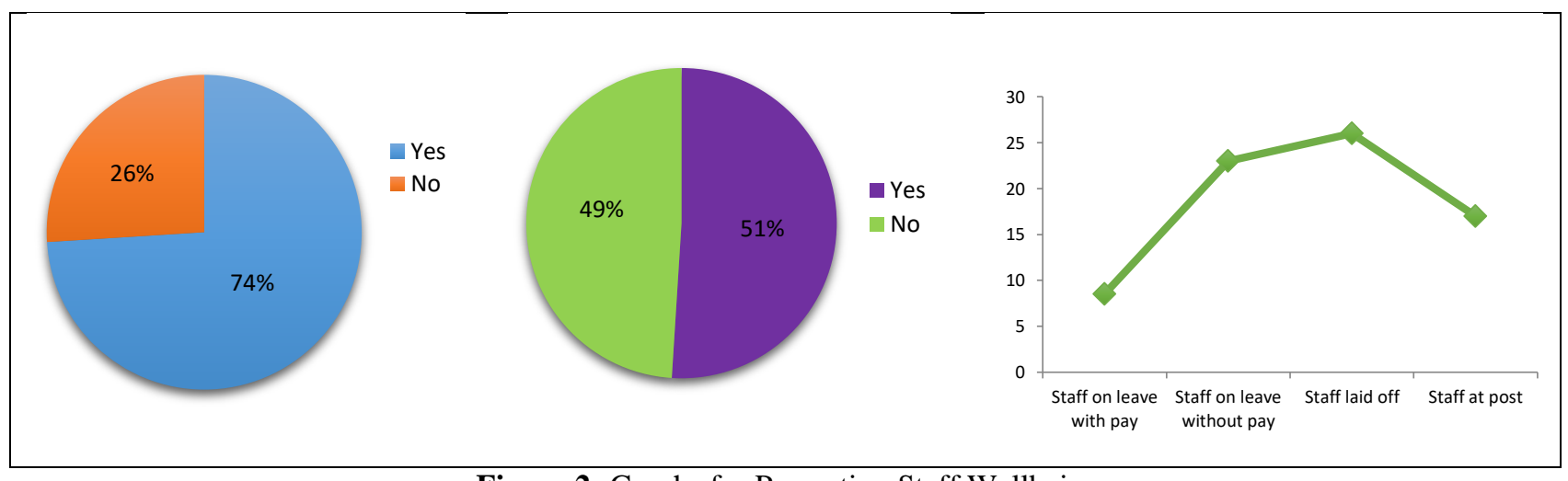

Source: Fieldwork June 2020

Figure 2: Graphs for Promoting Staff Wellbeing

From the multiple responses obtained from the survey and the interview session conducted to ascertain how staff have been affected as shown by Figure 2(c), it was revealed that most staff (casual) were laid off during the pandemic because of lack of funds to pay them. Staff layoffs have a direct and indirect effect on the employees most of which were breadwinners to their families. Some were also on leave without pay pending re-opening. The COVID-19 pandemic has therefore posed an important risk not only for hotels revenue streams but has negatively affected the economic well-being of its staff.

\section{Likely Post COVID-19 Effects on Ghanaian hotels}

The important factors one can look at is the likely repercussions COVID-19 can pose on the Ghanaian hotels after remedies (vaccines) have been found or the virus is minimally down and gone. We considered the post effects of COVID-19 on different areas of the hotels such as service patronage, prevention mechanisms, and how the hotels can survive, respectively. 


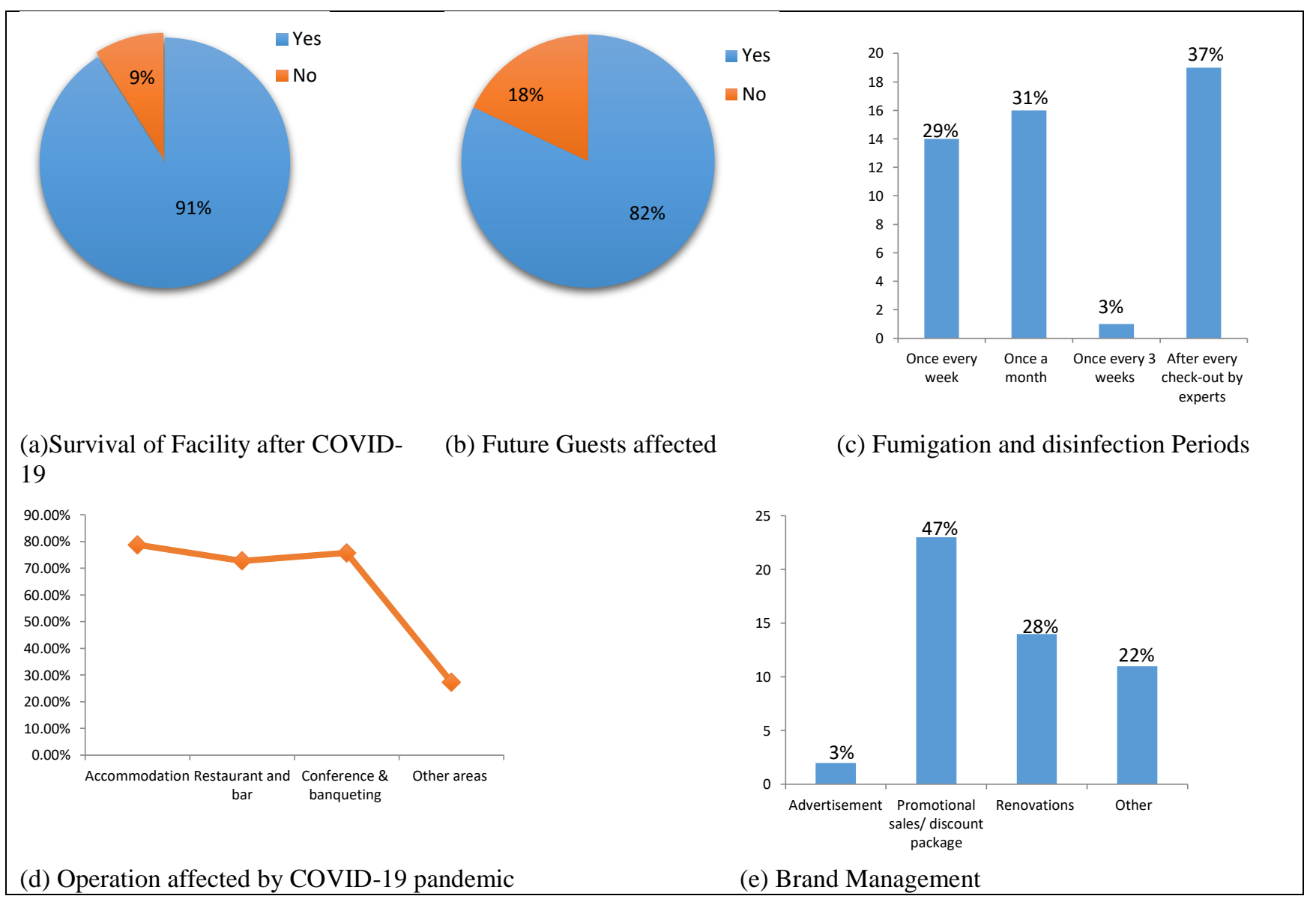

(a)Survival of Facility after COVID 19

(d) Operation affected by COVID-19 pandemic

Figure 3: Graphs on Likely Post COVID-19 Effects on Hotels

Source: Fieldwork June 2020

Figures 3(d) and 3(b) shows how the services rendered by the hotels and future guests would be affected after the COVID-19 spread, respectively. In Figure 3(d), multiple responses from the survey shows that accommodation, restaurant \& bar, conference and banqueting which are the major revenue generating activities are mostly affected by the COVID-19. Also, Figure 3(b) shows that over 80 percent of the respondents were certain that future guests will be affected in a post COVID-19 era. Guest needs and requirements will change drastically.

Several prevention methods and hygiene practices will have to be used by the management of 3-5 star rated hotels in Ghana. One of such mechanism that is capital intensive is fumigation and disinfection. Figure 3(c) indicates that fumigations and disinfections will take place very frequent especially after the checkout of a guest as proposed by the hotel managers, supervisors of units and staff. Also, other mechanisms such as the strict use of protective personal equipment (PPEs) and checking of temperature via temperature gun are adhered to in day-to-day activities. This shows that the hotel owners will have to be concerned about the safety of their guests. Guests will only select hotels if they can be assured of their safety. Brands, which will offer this, will become preferred choices.
Some hoteliers are optimistic business will return to normal. It is possible that COVID-19 will no longer be considered as a pandemic $r$ even an epidemic. There is still a lot of knowledge to be acquired in the post-COVID-19 era (post-crisis). All that can be said now are merely speculations. This is when hotel owners and managers will learn a lot from the pre-crisis and crisis response phase.

Figures 3(a) and 3(e) shows the survival rate of the hotels and measures taken to keep the hotels running respectively. In Figure 3(a), it can be seen that over $90 \%$ are certain that their business will be revived in a post COVID-19 era. Though majority are certain of a comeback over $19 \%$ who were afraid of the unknown, they lacked enough funds and lacked the required expertise to manage the post COVID-19 procedure.

Most hotel owners envisage managing their brands in a Post COVID-19 era by engaging in promotional sales, discounts and renovations. However, majority of the hotels will engage in promotions than the other options as shown in Figure 3(e). 


\section{CONCLUSIONS AND}

\section{RECOMMENDATIONS}

Conclusion

The COVID-19 pandemic has greatly affected the whole world; industry and people. The novel virus as it is also known has made it necessary for changes in the routine way of life to foster growth. It is uncertain when activities will return to normal that is if it will ever be. Currently, for human existence, it is necessary for adjustment to be made in all areas of life.

It has become obvious that, the novel COVID19 has negatively affected individuals, families, society, industries, and the world at large.

With regards to the objectives of the study which sought to find out the existing and possible after effects of the pandemic on the hotels in Ghana, it was realized that the hotels in Ghana (3-5 star rated) have undoubtedly been affected by the COVID-19 Pandemic and as such anticipating ease of the restrictions, lifting of bans on social gatherings, reopening of the closed boarders, though they remain uncertain. The effect on the hotel industry in Ghana is negative but we can also not rule out some positive impact. As per the responses from the interview and observations made overall, invariably we are in an era where health concerns has become paramount than before thus, hotels need to adapt to the current norm to ensure guests comfort and safety.

\section{Recommendation}

The researchers recommend the following activities for industry players' consideration to help revive and sustain the hotel industry in Ghana:

The need to develop a national or business level disaster management system that works to mitigate the impact of pandemics on business operations

Ensuring the safety of staff and guests in this pandemic era through the strict adherence of health and safety protocols is essential. Daily updates of COVID19 education on the hotel website with input from scientists can better help their customers in making informed decisions.

Since it is unknown when the social distancing rule will end in Ghana and across the world, restaurants should rather focus on improving take-outs and deliveries to the doorstep of customers. Hotel owners should be ready to re-strategize by adopting models that will help them stay afloat.

Industry players should sign up to insurance policies that can help cushion their businesses in times of crises
The use of discounts and promotions in relation with proper disinfection and cleaning protocols to attract guests who are now conservative in an effort to protect themselves from contracting the virus.

The use of virtual meetings in place of face-to-face is a novelty that has a lot of advantages including reducing the risk of movement and the saving travel resource

(Barrister Stead, 2014). Again, digitalization such as social media tools with good content development is one major area industry players need to invest in if they want to advertise and remain relevant in a pandemic situation. For instance, Ghana can lead the way in the organization of virtual concerts that projects the unique falls, forest reserves, game, and museums to create further awareness and keep the nation on the tourism map. Specialized photographers and IT personnel who knows how to create good content can be engaged to support the efforts. The COVID-19 pandemic has brought to light the use of ICT in bringing people together for meetings which business are taking advantage of.

Innovation - industry players should consider innovative ways to remain relevant. Healthier menus, air purifiers, scalability, enhanced check-in and hygienic in-house management of guests are areas to improve on.

Special attention to cleaning, disinfection and sterilization of both public areas and guest rooms. Staff should be trained to know the difference between cleaning; disinfection and sterilization to enable them perform jobs accurately and with utmost cleanliness in mind. Correct standard cleaning and disinfection measures should be followed to curtail the spread of infections and viruses in the hotel.

Education and training should be carried out in all hotels to enable staff to understand the nature of pandemics and post pandemic measures that could be undertaken to remain relevant

Hotels should form strong associations where knowledge sharing will be possible and where members can show solidarity to each other or weaker members in possible ways they can turn the negative side of COVID-19 into positive gains in the medium too long term

Additionally, we recommend hotels to either cite a clinic on their facility or have good-trained medical personnel to visit and check both staff and guests often.

Further, the extent of the bang of COVID-19 on the entire economies of destinations and entire hotel value chain requires government to provide leadership in managing the situation and introduce austerity measures to cushion business owners from the 
incapacitating effects of the pandemic. In this light the researcher further recommend these three scenarios for which the hotel industry in Ghana needs to prepare a response for ahead of re-opening of business;

- Possible event that a guest, visitor or employee contract COVID-19 while at the hotel.

- Possible events of a COVID-19 carrier checking into the hotel or enjoying other services apart from accommodation.

- The possibility of high drop in profits due to low patronage or non-patronage.

\section{Recommendation for further study}

The COVID-19 pandemic researches will by no little means add to knowledge in academia, health and industry. Further Research that can be carried out in the hotel industry includes researching about consumer behavior, risk management, business strategies to sustain hotel business and many others. Similar studies could also be done in other aspects of the hospitality and tourism industry. Further, research development will focus on knowledge gaps the research identified in pandemic management mechanisms; spending and costs associated with pandemic preparedness and response efforts are poorly tracked. Second, there is no widely accepted consistent methodology for estimating the economic impacts of pandemics. Finally, most of the data regarding the impacts of pandemics and costs of mitigating measures come from high-income countries which lead to biases and potential blind spots regarding the risk, consequences and optimal interventions specific to low and medium income countries as supported by, (Madhav et al.,, 2017).

\section{Author contributions}

All authors contributed to the paper accordingly. All authors have read and approved of the submission of this article.

\section{Funding}

This research received no external funding.

\section{Conflicts of Interest}

The authors declare no conflict of interest

\section{REFERENCES}

1. Abay, K. A., Tafere, K., \& Woldemichael, A. (2020). Winners and Losers from COVID-19: Global Evidence from Google Search. World Bank Policy Research Working Paper (9268).

2. Adom, D., Adu-Mensah, J., \& Sekyere, P. A. (2020). Hand-to-mouth work culture and the COVID-19 lockdown restrictions: experiences of selected informal sector workers in Kumasi, Ghana. Research Journal in Advanced Humanities, 1(2), 45-63.

3. Adu-Ampong, E. A. (2017). Divided we stand: Institutional collaboration in tourism planning and development in the Central Region of Ghana. Current Issues in Tourism, 20(3), 295-314.

4. Amewu, S., Asante, S., Pauw, K., \& Thurlow, J. (2020). The economic costs of COVID-19 in SubSaharan Africa: Insights from a simulation exercise for Ghana (Vol. 52): Intl Food Policy Res Inst.

5. Ansah, J. (2019). Institutional Choice And Recognition Vis-A-Vis Governance Outcomes In The Elmina Castle: A Political Economy Enquiry Into Tourism Management. UDS International Journal of Development, 6(3), 57-74.

6. Ary, D., Jacobs, L. C., Irvine, C. K. S., \& Walker, D. (2018). Introduction to research in education: Cengage Learning.

7. Ataguba, J. E. (2020). COVID-19 pandemic, a war to be won: understanding its economic implications for Africa: Springer.

8. Badu, K., Thorn, J. P., Goonoo, N., Dukhi, N., \& Sylverken, A. A. (2020). Africa's response to the COVID-19 pandemic: A review of the nature of the virus, impacts and implications for preparedness [version 1; peer review: awaiting peer review].

9. Bakar, N. A., \& Rosbi, S. (2020). Effect of Coronavirus disease (COVID-19) to tourism industry. International Journal of Advanced Engineering Research and Science, 7(4).

10. Baker, S. R., Bloom, N., Davis, S. J., Kost, K. J., Sammon, M. C., \& Viratyosin, T. (2020). The unprecedented stock market impact of COVID-19: National Bureau of Economic Research.

11. Becken, S., \& Carmignani, F. (2020). Are the current expectations for growing air travel demand realistic? Annals of Tourism Research, 80, 102840.

12. BOASIAKO, A. A. Drivers of Customer Satisfaction in the Hotel Industry in Ghana.

13. Boersch-Supan, A. H., \& Winter, J. K. (2001). Population aging, savings behavior and capital markets: National bureau of economic research.

14. Brady, M. T., Byington, C. L., Davies, H. D., Edwards, K. M., Glode, M. P., Jackson, M. A., . . . Orenstein, W. A. (2012). Recommendations for prevention and control of influenza in children, 2012-2013. Pediatrics, 130(4), 780-792.

15. Bundy, J., Pfarrer, M. D., Short, C. E., \& Coombs, W. T. (2017). Crises and crisis management: Integration, interpretation, and research development. Journal of management, 43(6), 16611692.

16. Chakraborty, I., \& Maity, P. (2020). COVID-19 outbreak: Migration, effects on society, global environment and prevention. Science of the Total Environment, 138882.

17. Chattu, V. K., Adisesh, A., \& Yaya, S. (2020). Canada's role in strengthening global health security during the COVID-19 pandemic. Global Health Research and Policy, 5(1), 1-3.

18. Cherkaoui, M. (2020). The Shifting Geopolitics of Coronavirus and the Demise of Neoliberalism(Part 2). Aljazeera Center for Studies, march, 19. 
19. Coombs, W. T. (2007). Protecting organization reputations during a crisis: The development and application of situational crisis communication theory. Corporate Reputation Review, 10(3), 163176.

20. Di Vaio, A., Boccia, F., Landriani, L., \& Palladino, R. (2020). Artificial Intelligence in the Agri-Food System: Rethinking Sustainable Business Models in the COVID-19 Scenario. Sustainability, 12(12), 4851.

21. Dube, K. (2020). Tourism and sustainable development goals in the African context. International Journal of Economics and Finance, 12(1).

22. Dwyer, L., Forsyth, P., \& Dwyer, W. (2020). Tourism economics and policy: Channel View Publications.

23. Edwards, J. S. (2020). An Overview of the Foodservice Industry. Handbook of Eating and Drinking: Interdisciplinary Perspectives, 983-1006.

24. Ehrlich, H., McKenney, M., \& Elkbuli, A. (2020). We Asked the Experts: Virtual Learning in Surgical Education During the COVID-19 Pandemic_-Shaping the Future of Surgical Education and Training. World Journal of Surgery, 1.

25. Fairlie, R. W. (2020). The Impact of COVID-19 on Small Business Owners: Continued Losses and the Partial Rebound in May 2020: National Bureau of Economic Research.

26. Fischer, J. E., \& Katz, R. (2013). Moving forward to 2014: global IHR (2005) implementation. Biosecurity and Bioterrorism: Biodefense Strategy, Practice, and Science, 11(2), 153-156.

27. Franco, D., \& Tommasino, P. (2020). Lessons From Italy: A Good Pension System Needs an Effective Broader Social Policy Framework. Intereconomics, 55, 73-81.

28. Gemar, G., Soler, I. P., \& Guzman-Parra, V. F. (2019). Predicting bankruptcy in resort hotels: a survival analysis. International Journal of Contemporary Hospitality Management.

29. Gössling, S., Scott, D., \& Hall, C. M. (2020). Pandemics, tourism and global change: a rapid assessment of COVID-19. Journal of Sustainable Tourism, 1-20.

30. Hartman, G., \& Nickerson, N. P. (2020). TourismRelated Business Owners Speak Out About COVID-19 Impacts.

31. Haryanto, T. (2020). COVID-19 PANDEMIC AND INTERNATIONAL TOURISM DEMAND. JDE (Journal of Developing Economies), 5(1), 1-5.

32. Hoarau, J.-F. (2020). Is international tourism responsible for the pandemic of COVID-19? A preliminary cross-country analysis with a special focus on small islands: TEPP.

33. Huang, C., Wang, Y., Li, X., Ren, L., Zhao, J., Hu, Y., . . . Gu, X. (2020). Clinical features of patients infected with 2019 novel coronavirus in Wuhan, China. The lancet, 395(10223), 497-506.
34. Hussain, S. A. (2020). Emerging Trends in Diplomacy, International Relations and Pakistan. Policy Perspectives, 17(1), 167-170.

35. Idris, M., \& Oruonye, E. (2020). Socioeconomic Impact of COVID-19 in Oil Exporting Countries: An Analytical Review of the Macroeconomic Indicators in Nigeria. International Journal of World Policy and Development Studies, 6(5), 4450 .

36. Ivanov, S., Webster, C., Stoilova, E., \& Slobodskoy, D. (2020). Biosecurity, automation technologies and economic resilience of travel, tourism and hospitality companies.

37. Jain, D. (2020). Effect of COVID-19 on Restaurant Industry-How to Cope With Changing Demand. Effect of COVID-19 on Restaurant Industry-How to Cope With Changing Demand (April 16, 2020).

38. Jedynak, T. (2020). Is it Still Possible to Receive an Adequate Income from Pensions in the Era of Ageing Societies?-The Great Pension Gap. Paper presented at the Eurasian Economic Perspectives: Proceedings of the 23rd Eurasia Business and Economics Society Conference.

39. Kabadayi, S., O’Connor, G. E., \& Tuzovic, S. (2020). The impact of coronavirus on service ecosystems as service mega-disruptions. Journal of Services Marketing.

40. Kantamneni, N. (2020). The impact of the COVID19 pandemic on marginalized populations in the United States: A research agenda: Elsevier.

41. Kickbusch, I., Leung, G. M., Bhutta, Z. A., Matsoso, M. P., Ihekweazu, C., \& Abbasi, K. (2020). Covid-19: how a virus is turning the world upside down: British Medical Journal Publishing Group.

42. Kim, K., Kim, S., \& Park, C.-Y. (2020). Food Security in Asia and the Pacific amid the COVID19 Pandemic.

43. Lederberg, J., Hamburg, M. A., \& Smolinski, M. S. (2003). Microbial threats to health: emergence, detection, and response: National Academies Press.

44. Lee, G. O., \& Warner, M. (2006). The impact of SARS on China's human resources: implications for the labour market and level of unemployment in the service sector in Beijing, Guangzhou and Shanghai. The International Journal of Human Resource Management, 17(5), 860-880.

45. Lestari, Y. D., \& Saputra, D. (2018). Market Study on Hospitality Sector: Evidence from 4/5-Star Hotel in Bandung City Indonesia. International Journal of Business \& Society, 19(1).

46. Lorde, T., \& Joseph, T. S. (2019). Airbnb, technological change and disruption in Barbadian tourism: a theoretical framework. Third World Quarterly, 40(12), 2190-2209.

47. Madhav, N., Oppenheim, B., Gallivan, M., Mulembakani, P., Rubin, E., \& Wolfe, N. (2017). Pandemics: risks, impacts, and mitigation.

48. Mensah, I. (2020). Waste management practices of small hotels in Accra: An application of the waste 
management hierarchy model. Journal of Global Business Insights, 5(1), 33-46.

49. Milojevic, D., \& Katsadze, B. (2020). Social Sustainability in COVID-19 Crisis: The Case of the Hotel Industry.

50. Nastopoulos, C. (2020). A Scenario-Based Analysis on the Impact of COVID-19 on the Public Sector, Private Sector, and International Business.

51. Nicola, M., Alsafi, Z., Sohrabi, C., Kerwan, A., AlJabir, A., Iosifidis, C., . . . Agha, R. (2020). The socio-economic implications of the coronavirus and COVID-19 pandemic: a review. International Journal of Surgery.

52. Niewiadomski, P. (2020). COVID-19: from temporary de-globalisation to a re-discovery of tourism? Tourism Geographies, 1-6.

53. Organization, W. H. (2018). Essential steps for developing or updating a national pandemic influenza preparedness plan: World Health Organization.

54. Organization, W. H. (2020). Coronavirus disease 2019 (COVID-19): situation report, 70.

55. Owusu-Fordjour, C., Koomson, C., \& Hanson, D. (2020). The impact of Covid-19 on learning-the perspective of the Ghanaian student. European Journal of Education Studies.

56. Ozili, P. K., \& Arun, T. (2020). Spillover of COVID-19: impact on the Global Economy. Available at SSRN 3562570.

57. Polyzos, S., Samitas, A., \& Spyridou, A. E. (2020). Tourism demand and the COVID-19 pandemic: an LSTM approach. Tourism Recreation Research, 113.

58. Ramelli, S., \& Wagner, A. F. (2020). Feverish stock price reactions to covid-19.

59. Ranasinghe, R., Damunupola, A., Wijesundara, S., Karunarathna, C., Nawarathna, D., Gamage, S., . . . Idroos, A. A. (2020). Tourism after Corona: Impacts of Covid 19 Pandemic and Way Forward for Tourism, Hotel and Mice Industry in Sri Lanka. Hotel and Mice Industry in Sri Lanka (April 22, 2020).

60. rekha Hanumanthu, S. (2020). Role of Intelligent Computing in COVID-19 Prognosis: A State-ofthe-Art Review. Chaos, Solitons \& Fractals, 109947.
61. Rhou, Y., \& Singal, M. (2020). A review of the business case for CSR in the hospitality industry. International Journal of Hospitality Management, 84, 102330.

62. Sansa, N. A. (2020). The Impact of the COVID-19 on the Financial Markets: Evidence from China and USA. Electronic Research Journal of Social Sciences and Humanities, 2.

63. Sarkodie, S. A., \& Owusu, P. A. (2020). Global assessment of environment, health and economic impact of the novel coronavirus (COVID-19). Environment, Development and Sustainability, 111.

64. Service, G. S. (2016). Population statistics: Ghana statistical service.

65. Smith, B. J., Tang, K. C., \& Nutbeam, D. (2006). WHO health promotion glossary: new terms. Health promotion international, 21(4), 340-345.

66. Smolinski, M., \& Hamburg, M. Lederberg JCommittee on Emerging Microbial Threats to Health in the 21st Century (2003) Microbial Threats to Health: Emergence, Detection, and Response: Washington DC: The National Academies Press.

67. Strong, A., \& Welburn, J. W. (2020). An Estimation of the Economic Costs of SocialDistancing Policies.

68. Thebault, R., Tran, A., \& Williams, V. (2020). African Americans are at higher risk of death from coronavirus-The Washington Post. The Washington Post.

69. Wang, Y., \& Wanjek, L. (2018). How to fix a lie? The formation of Volkswagen's post-crisis reputation among the German public. Corporate Reputation Review, 21(2), 84-100.

70. Yang, F. X. (2020). Social media friending in building coworker guanxi: A study in the hotel industry. International Journal of Hospitality Management, 84, 102183.

71. Zhang, D., Hu, M., \& Ji, Q. (2020). Financial markets under the global pandemic of COVID-19. Finance Research Letters, 101528.

72. Zhe, Z., \& Bawuah, S. (2019). The Effect of Adinkra Symbol Patronage on Tourism Growth in Ghana: The Mediating Role of Youth Awareness 